\title{
The Application of UPSUS PAJALE Program Technology on Rice
}

\author{
Z. Zulfitriyana, I.W. Syarfi and H. Hasnah*
}

\begin{abstract}
This study aims to identify the factors affecting the sustainable application of UPSUS PAJALE Program technology on rice in Solok Regency. The results reveal that among the four variables (farmer characteristics, nature of innovation, access to information and relative benefits) proposed to be related to the sustainability of the application of UPSUS PAJALE technology, the variable access to information is found to have strongest influence with $f 2$ value of 0.38 , while the variable nature of innovation contributes the smallest effect with $\mathbf{f} 2$ of 0.01 on the sustainability of the application of UPSUS PAJALE technology on rice. The characteristics of farmers and relative benefits have a moderate effect with $\mathbf{f} 2$ values of 0.14 and 0.17 , respectively. In order to encourage famers to apply the technology of UPSUS PAJALE on rice sustainably, it is suggested that the relevant agencies conduct socialization and provide technical guidance.
\end{abstract}

Index Terms - program sustainability, Structural Equation Modeling (SEM), technology application, UPSUS PAJALE

\section{INTRODUCTION}

Food commodities have received an important attention from Indonesian government, both central and regional, with various supporting policies to achieve national food security as a target of agricultural development. In 2015 the government determined the target to make Indonesia to be food self-sufficiency in 2019. In order to realize these objectives, the Ministry of Agriculture launched a special program on food crop development focusing on rice, corn and soybean, which is known as "Upaya Khusus Padi Jagung dan Kedelai (UPSUS PAJALE) Program". The program aims to increase the productivity of rice, maize and soybean to support the national objective to attain food selfsufficiency.

The technologies implemented in UPSUS PAJALE program include: use of superior/certified seedlings, the use of agricultural machinery and equipment technology, the application of Legowo row planting technology, and the application of the cultivation technology of the Rice of Intensification System (SRI). Adopting these technologies is expected to increase food crop production (Agricultural Regulation of

Republic Indonesia No. 03/Permentan/ OT.140/2/2015). Based on empirical experience, the increase in crop production is greatly influenced by the quality of the seeds used and the application of technology in crop cultivation businesses, such as; the use of balanced fertilizers, the application of cultivation technology that is applied consistently.
UPSUS PAJALE program was implemented almost throughout Indonesia that has the potential and resources to cultivate food crops, particularly rice, maize and soybean. Solok Regency is one of potential areas for food crops cultivation, particularly rice [1]. The support from the government for this program includes provision of certified superior seed assistance, allocation of agricultural equipment and machine, technical assistance from extension workers /technical assistance for Jajar Legowo technology and SRI technology.

In the period of 2015 - 2017, Solok Regency obtained a budget allocation for the implementation of the UPSUS PAJALE program in the form of rice seed aid through the Department of Food Crops, Horticulture and Plantation of West Sumatra Province. However, due to national budget constraints, in 2018 Solok Regency no longer got rice seed aid to support the implementation of this program [2].

Implementation of the UPSUS PAJALE program in Solok district have shown good results. During the implementation of program (2015 - 2017), the average of rice yield increased from 4.93 to 5.73 tons/ha. There was a slight decrease in rice yield to 5.70 tons/ha in 2018 [3]. There is an indication that discontinued support from the program cause rice yield to decline because farmers may no longer continue the application of UPSUS technologies post-program. This condition can restrain the sustainability of the program.

The success of a development program can be seen from the achievement of program objectives that have been set by applying the selected technology. Therefore, for the continued implementation of a program it is necessary to apply the use of program technology in a sustainable manner [4].

Innovation adoption can bring various impact on agricultural product performance. It can increase productivity but it also increases workloads. It cannot guarantee to increase profitability unless different marketing scenarios is developed [5].

Adoption is a decision to fully implement an innovation as the best action available after going through the stages of the adoption process [6]. Adoption decision by farmers cannot be homogenous across types of technologies and farm households due to variations in output market, production factors, and information; the diffusion process, adoption potential, and effectiveness [7]. Previous studies reveal that technology adoption can be influenced by various factors. Reference [8] categorized them into six dimensions including socio-economic, agro-ecological, institutional, 
informational, perceived attributes and psycho-social factors. More precisely, the adoption of an innovation can be affected by age, education, courage to take risks, relationship patterns, attitudes toward change, motivation to work, aspirations, fatalism and certain belief systems [9].

Moreover, the characteristics of innovation and prospective users, adoption decision making, the media channels used, conditions of extension [10], relative advantage, compatibility, level of complexity, testability and observability [11] are other factors that influence the adoption of innovations.

As the adoption decisions of improved technologies can be varies across the locations due to local environmental factors, this study aims to analyze factors affecting farmers to keep applying the technologies of UPSUS PAJALE in the post-program period. This study can fill in the gap in farmers' adoption decision assessment of innovation in rice production context.

\section{METHODOLOGY}

The study was conducted in Solok Regency in June October 2019 involving 105 sample farmers. Solok Regency was selected as research site purposively because it is rice production centers in West Sumatra and assigned to implement the UPSUS PAJALE program in the year 2015 2017 with the second largest of funding. In addition, Solok has no longer received funding for rice seed in the implementation of UPSUS PAJALE program since 2018. A survey instrument was developed to collect information using questionnaire.

We proposed a structural model of the sustainability of UPSUS PAJALE technology application (П) that are influenced by four factors: farmer characteristics ( $\xi 1)$, innovation characteristics ( $(2)$, information access ( $\xi 3)$ and relative benefits $(\xi 4)$. Indicators of the variables are presented in Table 1 .

Table 1. Indicators for Measurement of Research Variables

\begin{tabular}{|c|c|}
\hline Variable & Indicators \\
\hline $\begin{array}{l}\text { Continuity } \\
\text { Application of } \\
\text { Technology } \\
\text { UPSUS } \\
\text { PAJALE } \\
\text { (I) }\end{array}$ & $\begin{array}{l}\text { Application of Superior/Certified Seed Technology (Y1) } \\
\text { Application of Agricultural Equipment and Machinery } \\
\text { Technology (Y2) } \\
\text { Application of Jajar Legowo Planting Technology (Y3) } \\
\text { Application of System of Rice Intensification Technology } \\
\text { (Y4) }\end{array}$ \\
\hline $\begin{array}{l}\text { Farmer } \\
\text { Characteristics } \\
(\xi 1)\end{array}$ & $\begin{array}{l}\text { Farmer's Age (X1); } \\
\text { Famers' level of education (X2) } \\
\text { Land size (X3) } \\
\text { Availability of capital (X4) } \\
\text { Farmers' experience (X5) }\end{array}$ \\
\hline $\begin{array}{l}\text { Innovation } \\
\text { characteristics } \\
(\xi 2)\end{array}$ & $\begin{array}{l}\text { The Complexity of innovation (X6) } \\
\text { Communicative innovation (X7) } \\
\text { Suitability of innovation (X8) }\end{array}$ \\
\hline $\begin{array}{l}\text { Information } \\
\text { access } \\
(\xi 3)\end{array}$ & $\begin{array}{l}\text { Number of socialization/technical guidance meeting } \\
\text { attended by farmers (X9) } \\
\text { Number of group meetings during the UPSUS PAJALE } \\
\text { program (X10) } \\
\text { Number of group meetings attended by farmers (X11) } \\
\text { Number of trainer / advisory visits during the UPSUS } \\
\text { PAJALE program (X12) }\end{array}$ \\
\hline $\begin{array}{l}\text { Relative } \\
\text { Benefits } \\
(\xi 4)\end{array}$ & $\begin{array}{l}\text { Reduction of production costs (X13) } \\
\text { Availability of superior/certified seeds (X14) } \\
\text { Increased production (X15) }\end{array}$ \\
\hline
\end{tabular}

DOI: http://dx.doi.org/10.24018/ejfood.2020.2.3.23
The hypothetical model of the study is presented in Figure 1. The relationship between the sustainability of UPSUS $P A J A L E$ technology application (П) and variables of farmer characteristics $(\xi 1)$, nature of innovation $(\xi 2)$, access to information $(\xi 3)$ and relative profit $(\xi 4)$ is called the inner model. The relationship between latent variables and the manifest (indicator) variables is called the outer model. The magnitude of the relationship between manifest variables towards endogenous latent variables and exogenous latent variables is represented by the parameter lambda $(\lambda)$ produced by each manifest variable, that is also called the loading factor. Errors for measuring exogenous manifest variables are indicated by the delta parameter $(\delta)$ and errors for measuring endogenous manifest variables are shown by the epsilon parameter $(\epsilon)$.

Partial Least Square technique (PLS) was employed in this study to determine the factors influencing the sustainability of the application of UPSUS PAJALE technology in Solok Regency using Smart-PLS software. PLS approach was conducted in 4 steps: (a) Designing structural models (inner model); (b) Designing a measurement model (outer model); (c) Designing a path diagram construction; and (d) Evaluate PLS results.

\section{RESULTS AND DISCUSSION}

\section{A. The dimension of the Sustainability of UPSUS PAJALE Technology Application on rice}

There are 5 latent variables and 15 indicators involved in this study. The relationship among latent variables and indicators are described as follow.

\section{Farmer Characteristics $(\xi 1)$}

Figure 2 shows that most farmers implementing the UPSUS PAJALE technology on rice in Solok Regency are still in their productive age $(76.19 \%)$. Reference [9] suggested that the younger farmers will have a high enthusiasm to find information about what they do not know and have a tendency to try the innovation.

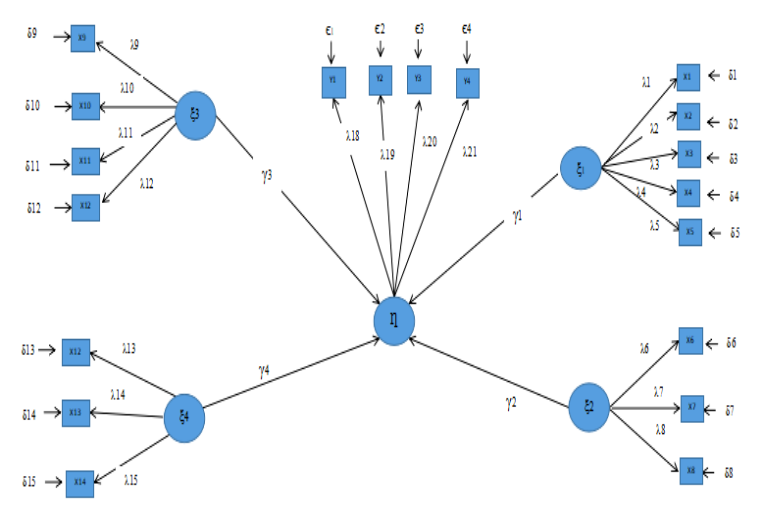

Fig. 1. Hypothetical model of Sustainability of UPSUS PAJALE Technology Application on Rice 


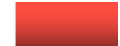

$23.81 \%$

Productive age (15 - 64 Tahun)

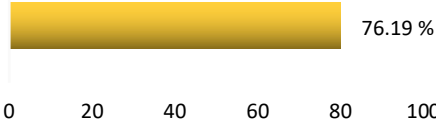

Fig. 2. Age of farmers

Figure 3 shows that more than $60 \%$ of farmers have completed high school. A person's educational background can normatively influence him in making decisions to adopt technology [12]. Farmer with a high educational attainment would be more motivated to adopt innovation [9].

Size of land cultivated by respondent farmers is described in Figure 4. More than $50 \%$ farmers implemented the technology for rice on small piece of land ( $\leq 0.5$ hectare). A study found that farmers who have more extensive land will find it easier and faster to adopt technology due to efficiency reasons in farming practices [13].

Generally, farmers implementing the UPSUS PAJALE program had sufficient capital to carry out the cultivation of rice, counting for $79.05 \%$ (Figure 5). The availability of sufficient capital is presumed to encourage farmers to adopt the technology for rice. Better economic capability could motivate farmers to adopt technology [13].

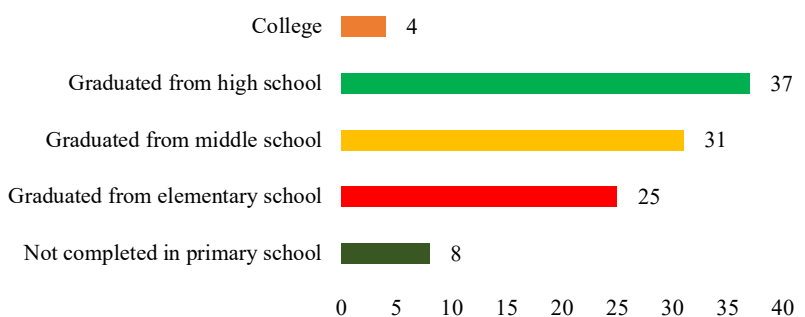

Fig. 3. Farmer Education Level (People)

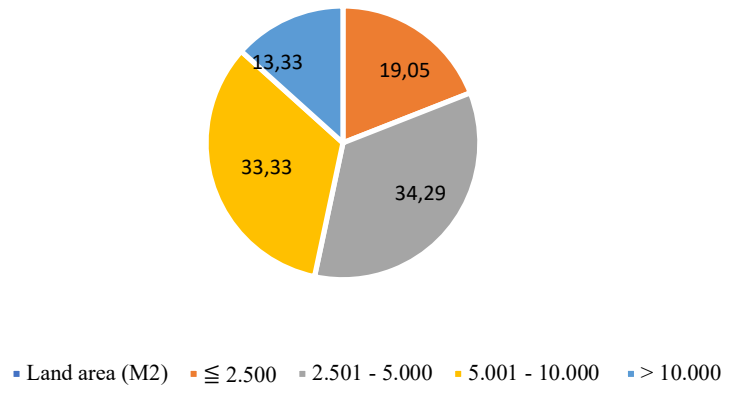

Fig. 4. Land size ownership (\%)

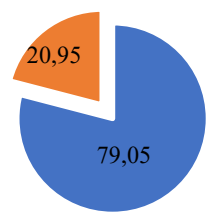

- Available Enough - Not Available Enough
Fig. 5. Capital availability (\%)

We found that participant farmers of UPSUS PAJALE program have quite a long experience on farm rice cultivation, where as many as $88.57 \%$ of farmers have more than 10 years' experience (Table 2). Experienced farmers may have a positive effect on the process of adopting UPSUS PAJALE technology. Farmers who have experience would more easily overcome the obstacles that occur in the field [14]. This characteristic will encourage him to take the decision to adopt technology.

\section{Characteristics of Innovation ( $(\xi 2)$}

Complexity of Innovation (X6) is one of indicators for measuring the nature of innovation (Table 3). Most farmers (56.20\%) disagree with statement that the UPSUS PAJALE technology for rice is a complex innovation. It means that most farmers found it easier to apply the technology on rice. About $43.80 \%$ farmers perceived that the technology is hard to implement. A technological innovation can be adopted by farmers if the innovation is technically easily implemented by farmers [15]. Technology that has a complex level of complexity will be more difficult for farmers to adopt.

About $67.63 \%$ of farmers quite agreed that the technology of the UPSUS PAJALE for rice was an easy technology to communicate. Communicative innovation will affect the adoption of innovation [10]. Innovations that are easy to communicate will be easy for farmers to adopt.

Table 2. Farmers' Experience on Farm Rice Cultivation

\begin{tabular}{ccc}
\hline Years of Experience & $\begin{array}{c}\text { Number of Farmers } \\
(\text { People })\end{array}$ & $\begin{array}{c}\text { Percentage } \\
(\%)\end{array}$ \\
\hline 10 & 12 & 11.43 \\
$11-20$ & 28 & 26.67 \\
$21-30$ & 16 & 15.24 \\
$31-40$ & 22 & 20.95 \\
$41-50$ & 21 & 20.00 \\
$>50$ & 6 & 5.71 \\
\hline Amount & 105 & 100.00 \\
\hline \hline
\end{tabular}

Table 3. Farmers' perception on the Technology Innovation of UPSUS PAJALE (\%)

\begin{tabular}{lccc}
\hline \hline Perception & Complexity & Communicative & Compatibility \\
\hline Strongly & 13.34 & 2.86 & 1.90 \\
Disagree & 42.86 & 29.52 & 12.38 \\
Disagree & 29.52 & 34.29 & 29.52 \\
Quite Agree & 12.38 & 19.05 & 42.86 \\
Agree & 1.90 & 14.29 & 13.33 \\
Strongly Agree & &
\end{tabular}

About $56.19 \%$ of farmers agreed that the technology of the UPSUS PAJALE for rice was a compatible innovation with the sociocultural, needs of farmers, and location-specific technological innovation. Compatibility will provide greater guarantees and less risk for the recipient. An innovation will be more compatible if the innovation is in accordance with 
the values and sociocultural beliefs and with ideas that are introduced first and already known by the recipient [10].

Reference [15] revealed that the suitability of the land cultivated with the technology used will encourage someone to adopt the technology. The use of technology in accordance with the location of the land being cultivated will increase the effectiveness of the business being carried out.

\section{Information access ( $\xi 3)$}

The variable of information access is measured by indicators: (a) Number of socialization/technical guidance meeting attended by farmers; (b) Number of group meetings during the UPSUS PAJALE program; (c) Number of group meetings attended by farmers; and (d) Number of trainer / advisory visits during the UPSUS PAJALE program.

Farmers who have sufficient knowledge and insight will be more motivated in adopting technology. Based on information obtained from the Department of Agriculture of Solok Regency that during the implementation of the UPSUS PAJALE program (2015 - 2017), training and socialization activities were carried out 12 times (4 times a year). The number of respondent farmers participating in training and outreach activities can be seen in Table 4 .

Most farmers (72.38\%) have learned information about the implementation of the UPSUS PAJALE program in Solok District through training and extension activities. Nonformal education has a significant relationship to the level of technology adoption, where the more often a person receives non-formal education, the easier and more motivated to adopt and apply technology [16]. Non-formal education can be obtained by farmers through training and extension carried out by the government both regional and central.

Survey results show that in general, farmers who participated in the UPSUS PAJALE program for rice, routinely hold group meetings. Figure 6 shows that during the implementation of the program (2015 - 2017), 67.71\% farmer groups had 36 times group meeting and the rest $(32.39 \%)$ held $<36$ meetings.

Table 4. Number of Training / Socialization Participated by Farmers

\begin{tabular}{|c|c|c|}
\hline $\begin{array}{l}\text { Training and Awareness } \\
\text { followed }\end{array}$ & $\begin{array}{c}\text { Amount } \\
\text { (time) }\end{array}$ & Percentage ( \% ) \\
\hline 0 & 29 & 27.62 \\
\hline $1-4$ & 50 & 47.62 \\
\hline $5-8$ & 1 & 0.95 \\
\hline $8-12$ & 25 & 23.81 \\
\hline Total number & 105 & 100.00 \\
\hline
\end{tabular}

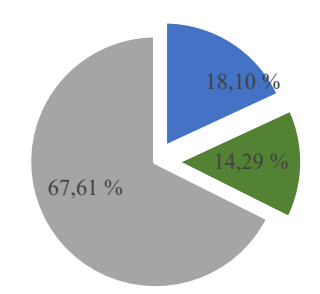

- 12 Times $\quad-18$ Times $\quad=36$ Times

Fig. 6. Number of Group Meetings during the Implementation of UPSUS PAJALE Program

Most farmer groups are considerably active. Based on information from the group, this routine meeting was still held by the farmer group management even though the agriculture meeting was not attended by the agriculture instructor. More frequent group meetings may have a positive impact on the continued adoption of UPSUS PAJALE technology. Counseling conducted through group meetings is an effective means of directing farmers to adopt technology [17]. Farmer group meetings that are not routinely carried out will slow the rate of technology adoption by farmers.

About $58.09 \%$ of farmers attended more than 20 group meetings (Table 5). This indicates that farmers are quite active in group activities. The higher the frequency of farmers participating in counseling, the faster farmers adopted technology [18].

The intensity of the visit of agricultural instructors is crucial in the continued implementation of UPSUS PAJALE technology at the farm level. Visits made by agricultural instructors and/or assistants during the implementation of the UPSUS PAJALE program in Solok Regency (2015 - 2017) is not routinely conducted every month. In Figure 7 can be seen that only $39.05 \%$ of agricultural extension workers and/or assistants who conduct field visits $\geqq 36$ times during the three years period. A study found that the intensity of counseling showed a significant correlation to the level of adoption of farmers in applying technology [17]. The lack of intensity of counseling carried out by officers resulted in the process of adopting Jajar Legowo technology being slow.

Table 5. Frequency of group meetings attended by Farmers

\begin{tabular}{lcc}
\hline \hline $\begin{array}{l}\text { The presence of farmers } \\
\text { in group meetings }\end{array}$ & $\begin{array}{c}\text { Number of } \\
\text { Farmers } \\
\text { (People) }\end{array}$ & $\begin{array}{c}\text { Percentage } \\
(\%)\end{array}$ \\
\hline$\leqq 10$ Times & 8 & 7.62 \\
$11-20$ Times & 36 & 34.29 \\
$21-30$ Times & 18 & 17.14 \\
$>30$ Times & 43 & 40.95 \\
\hline Amount & 105 & 100.00 \\
\hline \hline
\end{tabular}




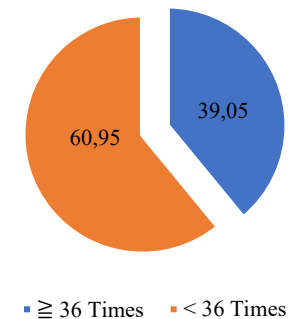

Fig. 7. Number of visits of Agricultural Extension Workers and/or Assistance Staffs (\%)

This figure indicates that agricultural extension workers and/or advisors did not carry out their duties properly, where more than $50 \%$ of agricultural extension workers and/or advisors do not make routine visits every month, as scheduled by the Department of Agriculture, Solok Regency. This can affect the continued implementation of UPSUS $P A J A L E$ technology in rice. The more frequent the counselors offered innovation, the better is the process of adopting innovation [10]. This can be realized if the instructor has the ability to communicate effectively using any means of communication.

\section{Relative Benefits ( $\xi 4)$}

The relative benefit variable is measured by three indicators, including reduction of production costs, availability of superior/certified seeds, and increased in production. Table 6 shows that most farmers $(89.53 \%)$ agreed that the implementation of the UPSUS PAJALE program can reduce production costs in the rice cultivation business. The reduction in production costs may motivate farmers to implement the cultivation business technology. For the adoption of a technology, it must be able to provide economic benefits, as an indicator for the efficiency of the use of the technology [15]. Efficiency in farming can be measured by reducing production costs. Achieving efficiency in farming will encourage farmers to adopt the technology. The use of machinery in the implementation of the UPSUS PAJALE program is thought to reduce labor usage and will have an impact on labor cost efficiency. Moreover, provision of free seeds or subsidies, increase in production, and increase in income are the incentive for farmers to adopt an innovation [11].

Table 6. Farmers' Perception on Relative Benefit of the UPSUS PAJALE technology (\%)

\begin{tabular}{lccc}
\hline \hline Perception & $\begin{array}{c}\text { Reduce } \\
\text { production costs }\end{array}$ & $\begin{array}{c}\text { Availability of } \\
\text { Certified Seeds }\end{array}$ & $\begin{array}{c}\text { Increase } \\
\text { Production }\end{array}$ \\
\hline Strongly Disagree & - & 2.86 & - \\
Disagree & 2.86 & 27.62 & - \\
Quite Agree & 7.62 & 33.33 & 8.57 \\
Agree & 74.29 & 20.00 & 63.81 \\
Strongly Agree & 15.24 & 16.19 & 27.62 \\
\hline Amount & 100.00 & 100.00 & 100.00 \\
\hline \hline
\end{tabular}

Superior/certified seed is one of the production facilities that must be used in the practice of the UPSUS PAJALE program at the farm level to increase production of agricultural products. To achieve its objectives, the program provides assistance/subsidies in form of superior/certified seeds for farmers who participated in the program. The availability of superior/certified seeds will greatly determine the sustainability of the application of UPSUS PAJALE technology at the farm level.

The results showed that $36.19 \%$ farmers agreed and strongly agreed to the availability of certified superior seeds when needed (Table 6). While farmers who stated they disagree and strongly disagree as much as $30.48 \%$. This number is quite a lot so that it will adversely affect the sustainability of UPSUS PAJALE technology application on rice in Solok Regency. The availability of facilities and infrastructure that supports farmers in adopting technology will influence the farmers' decision to adopt it [19].

The implementation of the UPSUS PAJALE program by application of Jajar Legowo planting technology, the System of Rice Intensification (SRI) technology, and the use of superior/certified seeds aims to increase production (Regulation of the Minister of Agriculture of the Republic of Indonesia No. 03/Permentan/OT.140/2/2015). All sample farmers have positive response on statement that increase in paddy production as an impact of the implementation of the UPSUS PAJALE Program. It was agreed by $63.81 \%$ farmers, even $28 \%$ farmers strongly agreed. This will have a positive impact on the sustainability of the application of UPSUS PAJALE technology in Solok Regency. Reference [12] found that the use of cultivation technology in agricultural businesses can increase production and increase income. The incentives received by farmers from increased production and income will encourage farmers to adopt technology.

\section{B. Structural equation modeling for the sustainability of the UPSUS PAJALE Technology Application in Solok Regency.}

The first step in conducting SEM analysis is to design a path diagram of the variables to be analyzed. The model is then tested for multicollinearity. The result of Smart PLS software analysis shows that the Variance Inflation Factor (VIF) value generated by each variable has a value of less than 10. This means that the data on the variable used is free from multicollinearity problems. The next step is evaluation of outer and inner model.

\section{Outer Model Evaluation}

The evaluation of outer model firstly involves convergent validity test. The convergent validity is indicated by the correlation between the indicator and the latent variable. It can be proved in two ways: through the achievement of criteria and through model comparison tests. In this study, the convergent validity is proved through the achievement of criteria. If the correlation value is more than 0.7 it can be said that the indicator has a high reflective measure of the indicator block, however in developing the measurement scale the correlation/loading value of $0.5-0.6$ is considered to have sufficient size for a measurement of validity. The 
results of the initial convergent validity stages are presented in Table 7 .

Indicator X3 has a loading factor smaller than 0.5. It means that with this poor convergent validity, the X3 indicator is not valid to measure the latent variable. Thus, it is removed from the model. Furthermore, the second stage of convergent validity test is performed. The second test of convergent validity results all the indicators have good convergent validity with factor loading value of greater than 0.5 .

Discriminant validity test results in the average variance extracted (AVE) value of all latent variables is greater than 0.50 , which are considerably good. All latent variables also have good composite reliability with value of $>0.7$ (Table 8).

\section{Inner Model Evaluation}

Evaluation of inner models is also called structural evaluation models. This evaluation aims to see the relationship between latent variables. The inner model is evaluated by using Goodness of Fit test.

Table 7. Results of Initial Convergent Validity

\begin{tabular}{lrrrrr}
\hline \hline & $\xi_{1}$ & $\xi_{2}$ & $\xi_{3}$ & $\xi_{4}$ & $\eta$ \\
\hline $\mathbf{X}_{1}$ & 0.6 & & & & \\
$\mathbf{X}_{2}$ & -0.7 & & & & \\
$\mathbf{X}_{3}$ & 0.0 & & & & \\
$\mathbf{X}_{4}$ & 0.5 & & & & \\
$\mathbf{X}_{5}$ & 0.8 & & & & \\
$\mathbf{X}_{6}$ & & 0.7 & & & \\
$\mathbf{X}_{7}$ & & 0.9 & & & \\
$\mathbf{X}_{\mathbf{8}}$ & & 0.9 & & & \\
$\mathbf{X}_{9}$ & & & 0.8 & & \\
$\mathbf{X}_{10}$ & & & 0.6 & & \\
$\mathbf{X}_{11}$ & & & 0.8 & & \\
$\mathbf{X}_{12}$ & & & 0.8 & & \\
$\mathbf{X}_{13}$ & & & & 0.6 & \\
$\mathbf{X}_{14}$ & & & & 0.8 & \\
$\mathbf{X}_{15}$ & & & & 0.9 & \\
$\mathbf{Y}_{1}$ & & & & & 0.5 \\
$\mathbf{Y}_{2}$ & & & & & 0.5 \\
$\mathbf{Y}_{3}$ & & & & & \\
$\mathbf{Y}_{4}$ & & & & & \\
\hline \hline
\end{tabular}

Table 8. Value of AVE and Composite reliability

\begin{tabular}{lcc}
\hline \hline \multicolumn{1}{c}{ Latent variable } & AVE & $\begin{array}{c}\text { Composite } \\
\text { reliability }\end{array}$ \\
\hline Farmer characteristics & 0.52 & 0.71 \\
Innovation characteristics & 0.70 & 0.88 \\
Information access & 0.60 & 0.86 \\
Relative benefits & 0.62 & 0.82 \\
Sustainability & 0.59 & 0.78 \\
\hline \hline
\end{tabular}

In this study, the Goodness of Fit from the Inner Model was measured by looking at the value of the Standardized Root Mean Square Residual (SRMR) and Normed Fit Index
(NFI). Recommended values to see the suitability of each model are SRMR $<0.05$ and NFI $>0.9$ [20]. The results show the SRMR value of 0.02 and NFI value of $>0.93$. It means the model has met the criteria for conformity test of the model (Goodness of Fit).

Inner model evaluation for endogenous constructs can be measured by R-square. Data analysis using smart-PLS software in the study results in the value R2 of 0.59 meaning that $59 \%$ the sustainability of UPSUS PAJALE technology application on rice can be explained by the four exogenous variables (farmer characteristics, nature of innovation, access to information and relative profits), the remaining $41 \%$ is explained by other variables not measured in the study.

Furthermore, changes in the R-square value are used to assess the effects of certain exogenous latent variables on endogenous latent variables, that can be measured by the value of $\mathrm{f}^{2}$. The values of $\mathrm{f}^{2}=0.02,0.15$ and 0.35 can be interpreted respectively that the predictor variables have a small, medium and large influence on the structural level [21].

Our study found that the nature of innovation has little effect on the sustainability of the UPSUS PAJALE technology application on lowland rice (Table 9). While variables of farmers' characteristics and relative benefit have moderate effect. Access to information has $\mathrm{f}^{2}$ value above 0.35 that indicates that access to information, has as strong influence on the sustainability of the UPSUS PAJALE technology application on lowland rice.

Table 9. f -Square Value

\begin{tabular}{lc}
\hline \hline \multicolumn{1}{c}{ Variable } & $\mathrm{f}^{2}$ \\
\hline Farmer characteristics & 0.14 \\
Innovation characteristics & 0.01 \\
Information access & 0.38 \\
Relative benefits & 0.17 \\
\hline \hline
\end{tabular}

\section{Test the Hypothesis of the Path Coefficient Model}

Hypothesis testing conducted in this study is a causality analysis test to determine the relationship between latent variables. Causality analysis can be used to determine how much influence is occurring between exogenous latent variables and endogenous latent variables [22].

Table 10. Estimation Results of Factors affecting the sustainability of the UPSUS PAJALE technology application on rice farming 


\begin{tabular}{|c|c|c|c|c|c|}
\hline $\begin{array}{c}\text { Tatent } \\
\text { Vaniable } \\
\text { Exogannous }\end{array}$ & Manifes Variabel & $\begin{array}{l}P_{\text {ath- }} \\
\text { Coef }\end{array}$ & $\begin{array}{c}\text { Loading } \\
\text { factor }\end{array}$ & $\begin{array}{c}\text { T- } \\
\text { Statistic }\end{array}$ & $\begin{array}{c}\text { p". } \\
\text { Vahes }\end{array}$ \\
\hline $\begin{array}{l}\text { Fanmes } \\
\text { Characteristics } \\
\text { (G, }\end{array}$ & 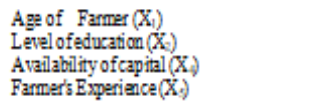 & 2.256 & $\begin{array}{l}-2.462 \\
1.949 \\
2.528 \\
2.236\end{array}$ & $\begin{array}{r}-1.932 \\
1.871 \\
2.506 \\
2.278\end{array}$ & $\begin{array}{l}0.02 \\
0.01 \\
0.02 \\
0.03\end{array}$ \\
\hline $\begin{array}{l}\text { Innovation } \\
\text { Charcterisitics } \\
\text { (5) }\end{array}$ & 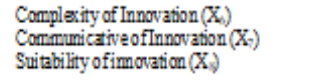 & 1.667 & $\begin{array}{r}-13.008 \\
44010 \\
24113\end{array}$ & $\begin{array}{r}-5.692 \\
14372 \\
9.619\end{array}$ & $\begin{array}{l}0.00 \\
0.00 \\
0.00\end{array}$ \\
\hline \multirow[t]{3}{*}{$\begin{array}{c}\text { Information } \\
\text { access } \\
(6)\end{array}$} & 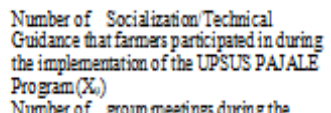 & 2.641 & 20586 & 9283 & 0.00 \\
\hline & 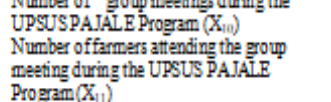 & & 10.796 & 7372 & 0.000 \\
\hline & $\begin{array}{l}\text { Nurber of Trainers Traing Visit during } \\
\text { the Progaram Implementation }\left(\mathrm{X}_{12}\right)\end{array}$ & & 19.613 & 6.731 & 0.00 \\
\hline \multirow{2}{*}{$\begin{array}{c}\text { Relative } \\
\text { Benefits } \\
(6)\end{array}$} & $\begin{array}{l}\text { Retuction in Production Costs }\left(X_{1}\right) \\
\text { Avaliability of Superiar Cortifitad Seadings }\end{array}$ & 1.948 & $\begin{array}{r}9.263 \\
14510\end{array}$ & $\begin{array}{l}3.876 \\
7376\end{array}$ & $\begin{array}{l}0.00 \\
0.00\end{array}$ \\
\hline & Inceasad Production $\left(\mathrm{X}_{1}\right)$ & & 68.110 & 11155 & 0.00 \\
\hline
\end{tabular}

") Significanceat $\alpha=0.05$

Table 10 shows that all exogenous latent variables have a probability value $(\mathrm{p}$-value $)<0.05$. This means that the four exogenous latent variables significantly influence the sustainability of the UPSUS PAJALE technology application on rice farming.

The study reveals that farmer characteristic significantly influences sustainability of the UPSUS PAJALE technology application on rice farming. It is similar result to findings by reference [23], where the characteristics of farmers greatly influence them in adopting an innovation. Soekartawi (1988) If the character of a community member supports a situation that allows for the adoption of innovation, the process of adopting innovation will run faster and better [9].

Of the four indicators (age, education level, capital availability and experience) used to measure the farmer characteristics variable, the indicator of capital availability is the most influential indicator. This means that the greater the capital owned by farmers, the motivation to adopt technological innovation will be higher. A better economic capability would make it easier for farmers to adopt technology [13].

Farming experience has a positive effect on farmers' characteristics. Longer farming experience can increase the motivation of farmers to adopt technological innovations. There is evidence of a close relationship between farming experience with the process of technology adoption [12].

The level of education of farmers also has a positive effect on farmers' characteristics. This means that the higher the level of education, the better the adoption of technological innovations by farmers. A person's educational background will normatively influence him in making decisions to adopt technology [12].

Age indicator shows a negative influence on farmer characteristic. It means that younger farmers have more motivation to adopt the technology. Younger farmers can have a higher enthusiasm to know what they do not know and tend to try new things [9].

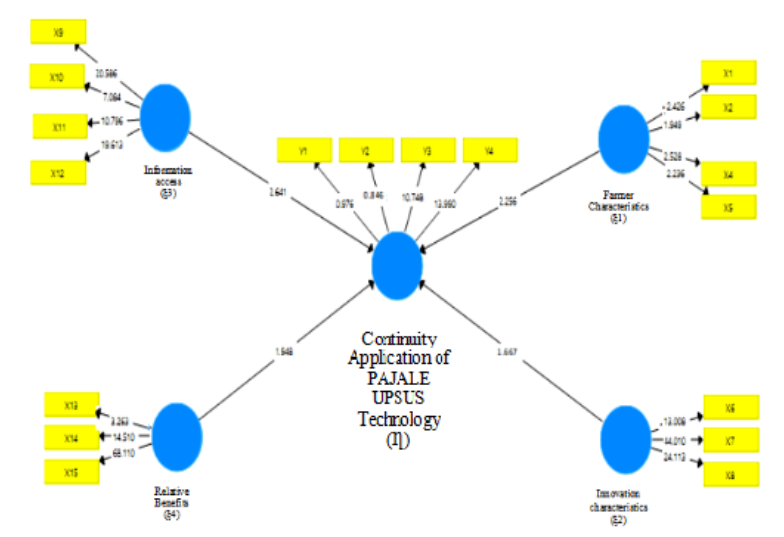

Fig. 8. Final model of Sustainability of UPSUS PAJALE Technology Application on Rice

The study shows that all indicators for innovation nature have larger t-statistic value than t-table vale (1.660) with $\mathrm{p}$ value of smaller than 0.05 . Of the three indicators, the communicative of innovation has the most positive and strongest influence with factor loading of 44.010 on innovation nature. This means that the more communicative an innovation is, the more motivated the farmer will be to adopt it. An innovation will be adopted by farmers if the innovation is technically easily understood by farmers.

The positive factor loading-value of suitability of innovation with local environmental conditions means that the more appropriate the innovation is with local environmental conditions, there will be greater rate of adoption for the innovation. Compatibility would provide greater assurance and less risk for the recipient. An innovation will be more compatible if the innovation is in accordance with the values and sociocultural beliefs [10].

The indicator of innovation complexity has a negative factor loading. This means that the higher the level of complexity of an innovation, the less the motivation to adopt the technological innovations. Moreover, the nature of innovation has a significant effect on the sustainability of UPSUS PAJALE technology application. Farmers' perceptions on the attributes of new technology may affect their adoption behavior [24].

Reference [10] distinguishes the characteristics of innovation into two: the nature inherent in the innovation itself (instinctive nature) and the nature of innovation which is influenced by environmental factors (extrinsic nature). Both characteristics of innovation can influence a person to adopt innovation. Intrinsic traits include; the advantages of innovation, the level of complexity, communicative innovation, trial-ability, and observability. While the extrinsic nature includes; compatibility of innovation with the local environment and the level of relative excellence of the innovations offered.

Access to information is another important variable that influence the sustainability of UPSUS PAJALE technology application. The adoption process that a person goes through at each stage is strongly influenced by the variety of sources of information in delivering an innovation [10]. This indicates that the variety of sources of information used by prospective adopters before adopting innovation, will affect the adoption of an innovation. The diversity of sources of information used shows that someone knows about an 
innovation and can provide information that mutually reinforces or complements an innovation. The diversity of information can be obtained by how the person can access information on an innovation.

In this study, measurement of information access variables used four indicators namely i.e. the number of socialization/ technical guidance attended by farmers, the number of group meetings, the number of farmers attending the routine group meetings, and the number of extension workers/advisors during UPSUS PAJALE program.

The results showed that the four measurement indicators have positive factor loadings. The number of socialization/ technical guidance attended by farmers has the greatest influence. This means that the more number of socialization/technical guidance that farmers attended, the better the adoption of UPSUS PAJALE technology innovations. This is in line with the results of research in reference [16] that non-formal education has a significant relationship with the level of technology adoption. The more often a person receives non-formal education, the easier it is to adopt and implement a technology. Non-formal education can be obtained by farmers through training and extension carried out by officers.

The next indicator that positively influences the nature of innovation in determining the sustainability of UPSUS $P A J A L E$ technology application on lowland rice in Solok Regency is the number of extension workers/assistants during the implementation of the UPSUS PAJALE program. It means that the higher the intensity of the number of extension workers/advisors during the UPSUS PAJALE program, farmers will be more motivated to adopt the program technology.

The number of farmers attending routine group meetings and the number of group meetings during the UPSUS $P A J A L E$ program have positive impact on continuation of technology application. The greater the number of farmers attending a routine group meeting and the greater the number of group meetings, the better the adoption process will be.

In this study, the relative profit variable is measured by indicators of reducing production costs, availability of superior/certified seeds, and an increase in production. Of the three indicators that have positive and the strongest influence is an increase in production. This means that the more production of agricultural products is obtained, the farmers will be more motivated to adopt the technology.

A person will adopt innovation if he will gain benefits as a result of implementing the innovation. There is a positive relationship between relative benefits and the adoption process [6]. Most experts claim that the most prominent indicator of relative profit influence on the adoption of innovation is the economic benefits, one of which is by increasing production. Reference [25] found that a higher income received by farmers from farming innovation encourage them to adopt the technology.

The availability of superior/certified seedlings encourage farmers to continue the application of UPSUS PAJALE technology for rice farming. The availability of facilities and infrastructure that supports farmers in adopting technology will influence the farmers' decision to adopt it [19]. In this case, the superior/certified seed is one of the infrastructures for the adoption of the technology that has been selected in DOI: http://dx.doi.org/10.24018/ejfood.2020.2.3.23 the implementation of the UPSUS PAJALE program.

Reducing production costs is another relative benefit that influences farmers in adopting a technology. The higher the reduction in production costs due to adopting technology, the more motivated farmers will be to adopt these technological innovations. The use of machinery in the implementation of the UPSUS PAJALE program can reduce labor use and will have an impact on labor efficiency.

An innovation will be adopted if the innovation can provide a relative benefit for the recipient of the innovation [11]. The relative benefit can be in the form of efficiency of production costs and the incentives obtained after implementing the innovation for example; provision of free seeds or subsidies, increased production and increased income.

\section{CONCLUSION}

We found that the characteristics of farmers, the nature of innovation, access to information and relative benefits have a significant influence on the sustainability of UPSUS $P A J A L E$ technology application on lowland rice. Access to information variables contributed the most powerful effect with $\mathrm{f} 2$ value of 0.38 , while innovation nature has the smallest effect with $\mathrm{f} 2$ value of 0.01 . The variable of farmers characteristics and relative benefits have a moderate effect, with $f 2$ values of 0.14 and 0.17 , respectively.

On the characteristics of farmers' variables, the indicator that has a positive influence and the strongest is the indicator of capital availability with an effect value of 2.528 , while the indicator that has a negative effect on this variable is the age indicator with an effect value of 2.462. In the nature of innovation, the most influential positive indicator is the communicative innovation indicator with an influence value of 44.010 and the indicator that has a negative effect is the innovation complexity with an influence value of 13.008. On the access to innovation variable, all indicators show a positive influence on the sustainability of the application of UPSUS PAJALE technology in lowland rice, where the indicator that has the most influence is the number of socialization/technical assistance activities attended by farmers during the implementation of the UPSUS PAJALE program, with an influence value of 20.586. On the relative profit variable, the indicator that has a positive effect with the most powerful influence is increasing production with a value of 68,110 .

These indicators require more attention to be improved to encourage famers to continue to apply the technology of UPSUS PAJALE on rice. It is suggested that the relevant agencies conduct socialization and provide technical guidance for farmers to apply that technology.

\section{ACKNOWLEGMENT}

The authors would like to thank Agriculture Office of Solok Regency, the Agricultural Extension Office of Kubung District, the Assistant Officer of the Kubung District, the Farmer Group in the Kubung District, the Head and membersof the Farmer Group in the Kubung District in providing data and information for this research. The results of the study are expected to be used as input for taking Vol 2 | Issue 3 | June 2020 
agricultural development policies in the future.

\section{REFERENCES}

[1] BPS-Statistics of Solok Regency, "Regency of Solok in figures 2017," : BPS-Statistics of Solok Regency, West Sumatra, 2018.

[2] Department of Food Crops Horticulture and Plantation of West Sumatra,"Report on the implementation of UPSUS PAJALE Program in 2018" Department of Food Crops, Horticulture and Plantation of West Sumatra Province, Padang, 2018.

[3] BPS-Statistics of Sumatera Barat Province, "Sumatera Barat Province in figure 2018, "BPS-Statistics of Sumatera Barat Province, Padang, 2018.

[4] W. Y. Harinta, "Factors affecting the speed of adoption of agricultural innovation among farmers in Gatak District, Sukoharjo Regency," Master, Universitas Sebelas Maret, Surakarta, 2010.

[5] J.-M. Blazy, P. Tixier, A. Thomas, H. Ozier-Lafontaine, F. Salmon, and J. Wery, "BANAD: A farm model for ex ante assessment of agroecological innovations and its application to banana farms in Guadeloupe," Agricultural Systems, vol. 103, pp. 221-232, 2010.

[6] E. M. Rogers, "Diffusion of Innovation 5th," ed. New York: The Free Press, 2003.

[7] A. Kumar, H. Takeshima, G. Thapa, N. Adhikari, S. Saroj, M. Karkee, et al., "Adoption and diffusion of improved technologies and production practices in agriculture: Insights from a donor-led intervention in Nepal," Land Use Policy, vol. 95, p. 104621, 2020.

[8] Y. S. Tey, "The adoption of sustainable agricultural practices: an integrative approach for Malaysian vegetable farmers," PhD, School of Agriculture, Food and Wine, The University of Adelaide, Adelaide, 2013.

[9] Soekartawi, "Basic principles of agricultural communication. Jakarta: UI Press, 1988.

[10] Mardikanto, "Redefinition and revitalization of agricultural education," Surakarta: Pasca Sarjana. UNS, 2002.

[11] A. W. Van Den Ban and A. S. Hawkins, Penyuluhan Pertanian (Agricultural Extension). Yogyakarta: Kanisius, 1999.

[12] Suharyono, "Factors influencing the acceleration of paddy rice technological innovation in Sarolangun Regency, Jambi," Jurnal Penelitian Universitas Jambi Seri Sains, vol. 17, 2017.

[13] A. S. Rondom., S. Supardi, and L. A. Sasongko, "Assessment of adoption level in integrated crop management (PTT) of paddy rice (Oryza Sativa. L) in Boja District Kendal Regency," Jurnal Ilmu-ilmu Pertanian.

[14] B. D. Saribu, "Factors influencing the process of adoption of rice field agricultural technology in Sumber Rejo Village, Pagar Merbau District, Deli Serdang Regency," 2013.

[15] A. Ali, "The influence of agricultural technology on rice productivity in the District of Maritengngae, Sindereng Rapang Regency," Muhammadiyah Rappang College of Social and Political Sciences, 2016.

[16] Winanti, "Correlation between farmers socio-economic factors with the adoption rate of Jatropra Curcas (L) Cultivation Technology Innovation in Lendah District, Kulon Progo Regency," Universitas of Sebelas Maret, 2018.

[17] H. Lalla, "Adoption of the legowo jajar planting system 2: 1 on paddy rice farmers in Polongbangkeng Utara District, Takalar Regency," Jurnal Sains \& Teknologi., vol. 12, 2012.

[18] Narti, "The Correlation between farmer's characteristics and the effectiveness of agricultural extension communication in the SL-PTT Program: Case of farmer groups in Kerkap District, North Bengkulu Regency," Universitas Bengkulu, 2015.

[19] R. Hanafie, "Introduction to agricultural economics," Yogyakarta: CV. Andi Offset, 2010.

[20] Sugiyono, "Statistics for research," Bandung: CV Alfabeta, 2010.

[21] I. Ghozali, "Structural equation modeling. alternative methods with partial least squares (PLS) 4ed," Semarang: Badan Penerbit Universitas Diponegoro, 2006.

[22] J. Sarwono and N. Umi, "Writing thesis and dissertation with Partial Least Square SEM (PLS-SEM)," Bandung: Andi Offset, 2014.

[23] K. Harisman, "Effect of Farmer group cooperation capabilities on the application of SRI (System of Rice Intensification) technology in Sumedang Regency," Jurnal ISTEK, vol. 8, pp. 217 - 228, 2014.

[24] J. M. D’Antoni, A. K. Mishra, and H. Joo, "Farmers' perception of precision technology: The case of autosteer adoption by cotton farmers," Computers and Electronics in Agriculture, vol. 87, pp. 121$128,2012$.

[25] R. E. Putri, L. T. W. Astuti, and N. Yanti, "Farmers Adoption of White Root Fungus Control Technology in Hevea Brasilliensis Muel. Arg in Aceh Tamiang," Young Vocational School, Agrica Ekstensia, vol. 10, pp. 8 - 18, 2016. 